\title{
Предиктори та детермінанти змагальної діяльності спортсменів у веслуванні
}

\section{Ольга Русанова}

\author{
Національний університет фізичного виховання і спорту України, Київ, Україна
}

Анотація. Стаття присвячена питанням систематизації прогностичних критеріїв, предикторів та детермінант ефективного подолання спортсменами різних змагальних дистанцій у веслуванні. Мета. Теоретично обгрунтувати та систематизувати критерії предикторів та детермінант змагальної діяльності веслувальників. Методи. Аналіз, систематизація та узагальнення даних літературних джерел. Результати. Реалізація методологічного підходу, спрямованого на забезпечення єдності та взаємозв'язку між структурою змагальної діяльності та підготовленості спортсменів-веслувальників, обумовлює субординаційні відносини між їхніми складовими, слугує основою для впорядкування процесу управління тренувальними та змагальними навантаженнями, забезпечує зв'язок структури змагальної діяльності та відповідної їй структури підготовленості з методикою діагностики функціональних можливостей спортсменів-веслувальників, характеристиками моделей різних рівнів, системою засобів і методів, спрямованих на вдосконалення компонентів підготовленості та змагальної діяльності. Серед найбільш значущих детермінант та предикторів результативних виступів веслувальників на різних змагальних дистанціях вчені розглядають антропометричні, морфологічні, фізіологічні характеристики; метаболічні показники та психологічні аспекти.

Відповідно до системи управління тренувальними і змагальними навантаженнями спортсменів у веслуванні, узагальнено та систематизовано предиктори результативних виступів веслувальників на різних змагальних дистанціях з урахуванням віку спортсменів. Доповнено теоретичні положення стосовно прогностичних критеріїв, предикторів та детермінант ефективного подолання спортсменами різних змагальних дистанцій у веслуванні.

Набули подальшого розвитку відомості про параметри прогнозування продуктивності веслувальників під час подолання дистанції 2000 м на веслувальному ергометрі. Ключові слова: детермінати, предиктори, веслування, змагальна діяльність.

\section{Olha Rusanova}

\section{PREDICTORS AND DETERMINANTS OF ROWERS' COMPETITIVE ACTIVITY}

Abstract. The article deals with the systematization of prognostic criteria, predictors and determinants of effective covering various competitive distances in rowing. Objective. Theoretically substantiate and systematize the criteria of predictors and determinants of competitive activity of rowers. Methods. Analysis, systematization and generalization of data from literature sources. Results. Implementation of the methodological approach aimed at ensuring the unity and relationship between the structure of competitive activities and training of rowers, conditions the subordinate relations between their components, serves as a basis for adjusting the management process of training and competitive loads, provides a link between the structure of competitive activities and its respective structure of fitness with methods of diagnostics of functional capabilities of rowers, characteristics of models of different levels, a system of means and methods aimed at improving the components of training and competitive activities. Among the most significant determinants and predictors of effective performances of rowers at different competitive distances, scientists consider anthropometric, morphological, physiological characteristics; metabolic parameters and psychological aspects

In accordance with the system of management of training and competitive loads of rowers, the predictors of their effective performance at different competitive distances are generalized and systematized with account for the age of athletes. Theoretical provisions concerning prognostic criteria, predictors and determinants of effective covering of various competitive distances in rowing are supplemented. Information on the parameters for predicting the performance of rowers while covering a $2000 \mathrm{~m}$ distance on a rowing ergometer has been further developed. Keywords: determinants, predictors, rowing, competitive activity.

Rusanova 0. Predictors and determinants of rowers' competitive activity. Theory and Methods of Physical education and sports. 2020; 4: 34-42 DOI: $10.32652 /$ tmfvs.2020.4.34-42
Вступ. На сучасному етапі розвитку спортивної науки підвищення дослідницького інтересу до теорії та методики підготовки спортсменіввеслувальників зумовлене професіоналізацією та популяризацією веслування академічного та веслування на байдарках і каное у світі завдяки проведенню чемпіонатів світу 3 веслування у Європі (Іспанія, Італія, Велика Британія), Америці (Канада, США) та інших регіонах, таких як Саудівська Аравія [40].

Веслування на байдарках і каное та веслування академічне - це олімпійські види спорту. У веслуванні на байдарках і каное жінки змагаються на дистанціях 200 та 500 м, а чоловіки - на 200 та 1000 м. У 2009 р. у веслуванні на байдарках і каное дистанція 200 м була включена до програми Олімпійських ігор, замінивши 500-метрові змагання серед чоловіків та надавши жінкам можливість виступати на дистанції 500 м.

Участь в Олімпійських іграх є пріоритетним завданням для переважної більшості елітних веслувальників. Тому модифікація програми Ігор Олімпіад у веслуванні на байдарках і каное у 2012 р., а саме вилучення дистанції 500 м 3 та включення дистанції 200 м, призвела до вимушеної переорієнтації спортсменів-веслувальників на дистанції 200 м або 1000 м (рис. 1). У веслуванні академічному юні спортсмени виступають на дистанції 1000 та 1500 м, юніори та юніорки, молодь та дорослі спортсмени - на дистанції 2000 м. Змагання на ергометрах проводять на дистанціях 6000 та 2000 м. Таким чином, у веслуванні академічному та веслуванні на байдарках і каное змагальна діяльність спортсменів охоплює дистанції від 200 до 6000 м, а також включає марафонські дистанції.

Під змагальною діяльністю розуміють інтегральну характеристику підготовленості спортсмена; сукупність дій спортсмена-веслувальника у процесі змагання, об'єднаних метою і об'єктивною логікою її реалізації $[6,7]$. 


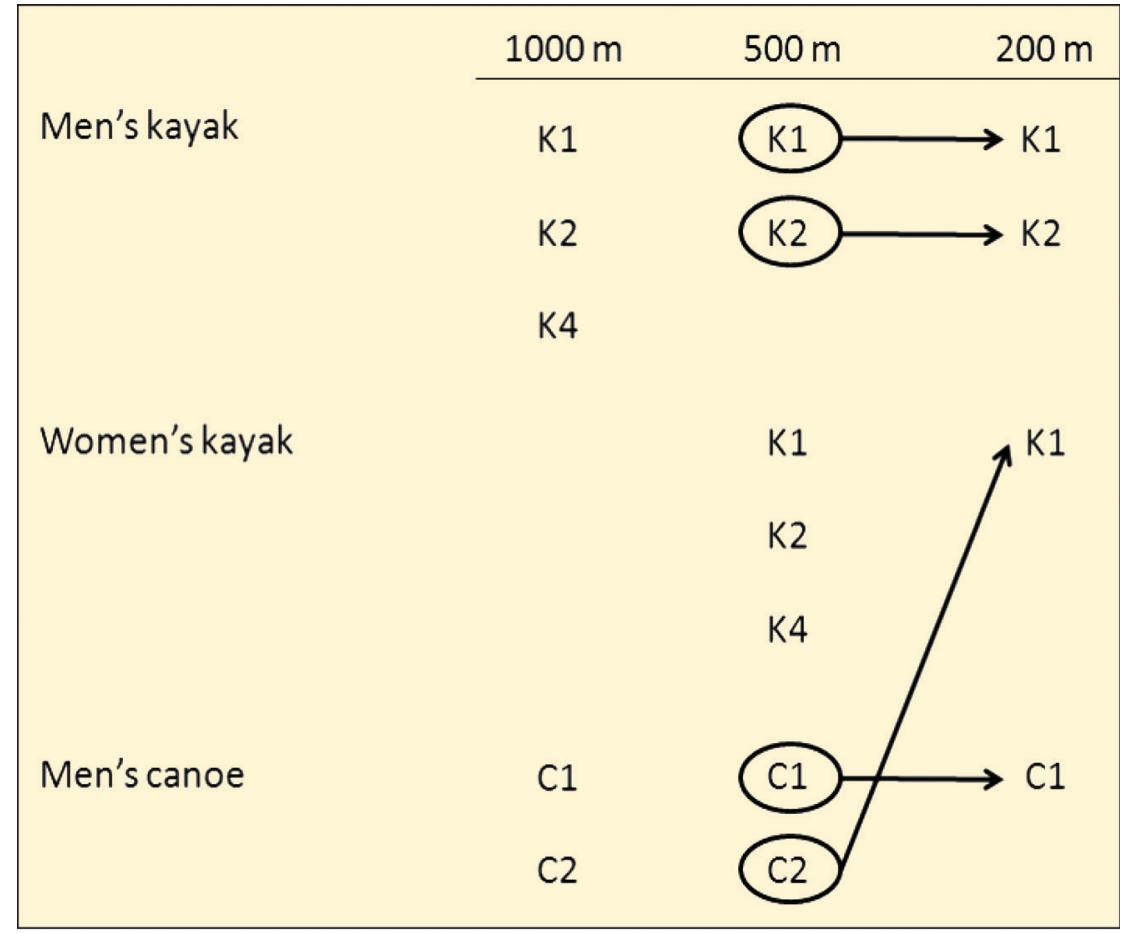

$\longrightarrow$ Re-arrangement of the Olympic program to London 2012 (ICF, 2009)

Рисунок 1 - Зміни у програмі Ігор Олімпіад у веслуванні на байдарках і каное у 2012 p. [16].

На думку В. М. Платонова, результат змагальної діяльності залежить від двох груп компонентів - забезпечення та реалізації [7]. Аналіз фракторів забезпечення та реалізації у кожному 3 видів спорту повинен розглядатися на основі чіткого виокремлення характеристик змагальної діяльності. Специфріка кожного з видів веслувального спорту має провідні елементи, що визначають результативність змагальної діяльності.

Реалізація методологічного підходу, спрямованого на забезпечення єдності та взаємозв'язку між структурою змагальної діяльності та підготовленості спортсменів-веслувальників, обумовлює субординаційні відносини між їхніми складовими, слугує основою для впорядкування процесу управління тренувальними та змагальними навантаженнями спортсменів у веслуванні, забезпечує зв'язок структури змагальної діяльності та відповідної їй структури підготовленості з методикою діагностики функціональних можливостей веслувальників, характеристиками моделей різних рівнів, системою засобів і методів, спрямованих на вдосконалення ком- понентів підготовленості та змагальної діяльності [7].

Науковцями доведено, що в умовах інтенсифікації, диверсифікації тренувального процесу, на фоні збільшення обсягу змагальної практики спортсменів у веслуванні, підвищення ефективності тренувального процесу здійснюється на основі аналізу даних про взаємозв'язок інфрормативних показників ефективності змагальної діяльності на певній дистанції і реакції організму на це змагальне навантаження [1-5, 9,10].

Не зважаючи на те що на основі діагностики функціональних можливостей веслувальників, зареєстрованих у спеціальних умовах тестування, доведено, що підтримання високого рівня спеціальної роботоздатності обумовлене ефективністю функціонального забезпечення, тому триває науковий пошук прогностичних критеріїв, предикторів та детермінант результативності спортсменів на певній змагальній дистанції.

Усвідомлення необхідності проведення досліджень у цьому напрямі привело до появи ряду робіт концептуального й практичного характе- ру. Багато авторів у своїх дослідженнях як предиктори результативних виступів веслувальників на різних дистанціях розглядають:

- антропометричні характеристики [11, 17, 28, 30, 31, 35];

- морфологічні характеристики [11, 30, 50];

- фрізіологічні характеристики [19, 21, 26, 27, 42];

- метаболічні показники [12, 21 , 42, 43];

- психологічні аспекти [29].

Проте варто зазначити, що перераховані прогностичні критерії потребують узагальнення та детальної систематизації з урахуванням вікових, гендерних, кваліфікаційних особливостей спортсменів-веслувальників.

Дослідження виконувалося відповідно до теми 2.9 «Побудова тренувального процесу висококваліфрікованих спортсменів, які спеціалізуються у водних видах спорту з урахуванням вимог змагальної діяльності» плану науково-дослідної роботи НУФВСУ на 2016-2020рр. (номер держреєстрації 0116U001614).

Мета дослідження: теоретично обґрунтувати та систематизувати прогностичні критерії, предиктори та детермінанти есективного подолання спортсменами різних змагальних дистанцій у веслуванні.

Методи дослідження: аналіз, систематизація та узагальнення даних літературних джерел.

Результати дослідження та їх обговорення. Увага дослідників у веслуванні академічному [21, 26, 28, 42-44, 53] та веслуванні на байдарках і каное [11] була зосереджена здебільшого на антропометричних та морфологічних характеристиках спортсменіввеслувальників. Відсутність комплексного характеру досліджень та проведення досліджень за участю спортсменів різної кваліфрікації, не давало можливості створити системне уявлення про предиктори та детермінанти результативних виступів спортсменів на певній змагальній дистанції.

Спроба систематизувати предиктори результативних виступів веслувальників на дистанції 2000 м на веслувальному ергометрі належить Jurimae J. et al. [28] (табл. 1). 
Т а б л и ц я 1. Параметри прогнозування продуктивності веслувальників під час подолання дистанції 2000 м на веслувальному ергометрі у дослідженнях різних авторів [28, доповнено автором]

\begin{tabular}{|c|c|c|c|c|}
\hline Автор & $\begin{array}{l}\text { Кількість спортсменів, } \\
\text { які брали участь у } \\
\text { дослідженнях }\end{array}$ & Параметри & $\begin{array}{c}\text { Рівень } \\
\text { надійності }\end{array}$ & Примітка \\
\hline $\begin{array}{l}\text { A. P. Russell et al. } \\
{[43]}\end{array}$ & $\begin{array}{l}19 \text { юнаків, спортменів- } \\
\text { школярів }\end{array}$ & $\begin{array}{l}\text { Зріст, маса тіла, товщина } \\
\text { шкірної складки }\end{array}$ & 0,78 & - \\
\hline $\begin{array}{l}\text { C. J. Womack et al. } \\
\text { [53] }\end{array}$ & $\begin{array}{l}10 \text { чоловіків, спортсменів } \\
\text { коледжу }\end{array}$ & $\begin{array}{l}\text { VO } 2 \text { max } \\
\text { Максимальна швидкість } \\
\text { Швидкість на рівні концентрації } \\
\text { лактату } 4 \text { ммоль } \cdot \pi^{-1} \\
\text { VO на рівні концентрації лакта- } \\
\text { ту } 4 \text { ммоль } \cdot \pi^{-1}\end{array}$ & 0,81 & $\begin{array}{l}\text { Тривалість інтервалу відпочинку } \\
\text { в додаткових тестах може мати } \\
\text { занадто великий вплив на } \\
\text { зареєстровані значення споживан- } \\
\text { ня кисню }\end{array}$ \\
\hline $\begin{array}{l}\text { M. J. Cosgrove et al. } \\
{[21]}\end{array}$ & $\begin{array}{l}13 \text { чоловіків, спортсменів } \\
\text { коледжу }\end{array}$ & $\begin{array}{l}\text { VO_max } \\
\text { Концентрація лактату у крові } \\
\text { на 5-й хвилині після подолання } \\
\text { дистанції } 2000 \text { м }\end{array}$ & 0,87 & $\begin{array}{l}\text { За участю однорідної групи } \\
\text { спортсменів }\end{array}$ \\
\hline S. Ingham et al. [26] & $\begin{array}{l}19 \text { чоловіків та } 13 \text { жінок } \\
\text { у відкритій ваговій } \\
\text { категорії, } 4 \text { чоловіки та } \\
5 \text { жінок у легкій ваговій } \\
\text { категорії }\end{array}$ & $\begin{array}{l}\text { Потужність роботи на рівні } \\
\text { VO }{ }_{2} \text { max, VO }{ }_{2} \text { та потужність ро- } \\
\text { боти при концентрації лактату в } \\
\text { крові } 4 \text { ммоль · } \text { л }^{-1} \text { і максималь- } \\
\text { на потужність роботи }\end{array}$ & 0,98 & $\begin{array}{l}\text { Недостатньо конкретні резуль- } \\
\text { тати через неоднорідність гру- } \\
\text { пи спортсменів, які брали участь у } \\
\text { дослідженні }\end{array}$ \\
\hline $\begin{array}{l}\text { S. E. Riechman et al. } \\
\text { [42] }\end{array}$ & $\begin{array}{l}12 \text { жінок, спортсменок } \\
\text { високої кваліфікації }\end{array}$ & $\begin{array}{l}\text { Потужність роботи у 30-секунд- } \\
\text { ному тесті, V0_max, втома }\end{array}$ & 0,96 & $\begin{array}{l}\text { Для прогнозування результатів на } \\
\text { дистанції було розроблено 30-се- } \\
\text { кундний тест }\end{array}$ \\
\hline J. Jurimae et al. [28] & $\begin{array}{l}10 \text { чоловіків, } \\
\text { веслувальників } \\
\text { національного рівня }\end{array}$ & $\begin{array}{l}\text { Максимальна потужність робо- } \\
\text { ти, } \text { La }_{350 w}, \text { зріст, м'язова маса }\end{array}$ & 0,99 & $\begin{array}{l}\text { Порівнює показники } \\
\text { роботоздатності під час веслування } \\
\text { на воді та на ергометрі }\end{array}$ \\
\hline $\begin{array}{l}\text { P. Majumdar et al. } \\
{[33]}\end{array}$ & $\begin{array}{l}139 \text { спортсменів легкої } \\
\text { вагової категорії та } 60 \\
\text { веслувальників відкритої } \\
\text { категорії }\end{array}$ & $\begin{array}{l}\text { Вік, зріст, вага та відсоток } \\
\text { жирової маси, силові характе- } \\
\text { ристики }\end{array}$ & 0,73 & - \\
\hline D. Cerasola et al. [19] & $\begin{array}{l}15 \text { веслувальників } \\
(15,7 \pm 2,0 \text { роки) } \\
\text { національного рівня }\end{array}$ & $\begin{array}{l}\text { Антропометричні характеристи- } \\
\text { ки, V0, max і } \mathrm{W}_{60} \text { - потужність } \\
\text { роботи у 60-секундному тесті }\end{array}$ & 0,94 & $\begin{array}{l}\text { 60-секундний тест можна було б } \\
\text { вважати цінним інструментом для } \\
\text { прогнозування виступу на дистанції } \\
2000 \text { м веслувальників-юнаків }\end{array}$ \\
\hline
\end{tabular}

Предиктори результативних виступів веслувальників на різних дистанціях з урахуванням віку спортсменів розглядалися у багатьох працях [19, 23, 33, 35, 45].

У роботі P. Mikulic [35] було обґрунтовано предиктори, що визначають результат на дистанції 1000 м на веслувальних ергометрах для 12-13-річних спортсменів. Результати регресійного аналізу дозволили розрахувати три прогностичні моделі. Прогностична модель 3 найнижчою надійністю $\left(\mathrm{R}^{2}=0,76\right.$, стандартна похибка 12,40) включає антропометричні показники: час на дистанції 1000 м = 403,31 - 3,06 (сухої маси тіла) + 1,41 (обхват стегна) - 6,72 (вік). Друга модель $\left(R^{2}=0,80\right.$, стан- дартна похибка 11,10) включала фізіологічні показники спортсменів: час на дистанції 1000 м = 396,25 - 39,28 $\left(\mathrm{VO}_{2} \max \right)-2,70$ (вік). Третя модель $\left(R^{2}=0,85\right.$, стандартна похибка 10,02), запропонована авторами, містила фізіологічні та антропометричні характеристики: час на дистанції 1000 м = $=497,58-29,26$ (V0, max) - 1,90 (біакроміальний діаметр) + 0,53 (обхват стегна) - 0,72 (маса тіла) - 0,37 (вік). Було зазначено, що під час відбору дітей та підлітків у веслуванні академічному тренери повинні зосередити свою увагу на спортсменах високого зросту з великою м'язовою масою, які мають аеробні можливості на рівні вище середнього [35].
Деякі учені досліджували швидкісно-силові спроможності 14-15-річних спортсменів-веслувальників на дистанції 1500 м. Встановлено тісний взаєм0зв'язок між результатом на цій дистанції та потужністю, зареєстрованою під час виконання стрибкових вправ [23].

H. Maciejewski et al. на основі peзультатів власних досліджень, наголошують на важливості врахування внеску анаеробних енергетичних шляхів у 1500-метрову змагальну дистанцію, одним 3 ключових предикторів ефективної змагальної діяльності вважають відсоток м'язової маси у веслувальників-підлітків; модифікований 30-секундний максимальний тест може бути використаний трене- 
рами 3 веслування для потенційного виявлення талановитих молодих спортсменів [32].

Інші дослідження присвячені питанням прогнозування виступів веслувальників (15,7 $\pm 2,0$ роки) на дистанції 2000 м на веслувальному ергометрі із застосуванням антропометричних показників веслувальників національного рівня, максимального поглинання кисню та потужності роботи у 60-секундних тестах. Абсолютні значення $\mathrm{W}_{60}$ і $\mathrm{VO}_{2} \max$ становили 476,1 $\pm 91,0$ Вт та 4669,0 \pm $\pm 842,0$ мл $\cdot$ хв $^{-1}$ відповідно, відносне споживання кисню зареєстроване на рівні 65,8 $\pm 8,7$ мл $\cdot \mathrm{Xв}^{-1} \cdot \mathrm{K}^{-1}$ відповідно. Час подолання дистанції 2000 м на веслувальному ергометрі становив $417,1 \pm 21,8$ с. Поєднання антропометричних характеристик, $\mathrm{VO}_{2} \max$ i $\mathrm{W}_{60}$ показників виявилися найнадійнішим рівнянням для прогнозування $\mathrm{t} 2000$ $(\mathrm{R} 2=0,94$, SEE $=6,4)$ [19].

$\mathrm{y}$ роботі «Contributions of Anthropometric and Strength Determinants to Estimate 2000 m Ergometer Performance in Traditional Rowing» дослідники відзначають важливість врахування антропометричних характеристик під час прогнозування результативності на дистанції 2000 м [45].

Доводиться констатувати, що лише окремі дослідження присвячені детермінантам результативних виступів веслувальників на різних змагальних дистанціях з урахуванням вагової категорії [20, 24, 36, 38, 39].

Деякі учені досліджували фрізичні та силові показники як провісники результативності кваліфрікованих спортсменів на дистанції 2000 м на веслувальному ергометрі. У дослідженнях взяли участь 139 спортсменів легкої вагової категорії та 60 веслувальників відкритої категорії. Авторами розроблено регресійні рівняння, що висвітлюють зв'язок результату на дистанції 2000 м на веслувальному ергометрі 3 фізичними показниками та силовими характеристиками спортсменів. Результати досліджень виявили у веслувальників відкритої категорії, порівняно зі спортсменами легкої вагової категорії, вищу масу тіла (10,3\%, $p<0,0001)$, зріст $(1,9 \%, p<0,0001)$, вік $(8,2 \%, p<0,01)$, відсоток жиру в організмі (18,2\%, p < 0,0001), ендоморф $(30,3 \%, p<0,0001)$, мезоморф $(17,8 \%, p<0,0001)$, силу спини $(8,9 \%, p<0,0001)$, силу зчеплення правою рукою $(5,8 \%, p<0,001)$, силу зчеплення лівою рукою (6,5\%, $p<0,001)$, менший ектоморф $(14,1 \%$, $p<0,001)$ і менший час на дистанції 2000 м (2,2\%, p < 0,0001). Час подолання дистанції тісно ( $p<0,001)$ корелював з віком $(r=-0,459)$, зростом $(r=-0,340)$, вагою $(r=-0,506)$, силовими показниками спини $(r=-0,458)$, правої руки ( $r=-0,311)$ та лівої руки $(r=-0,333)$. Багаторазовий регресійний аналіз виокремив сильні предиктори результативності на дистанції 2000 м на веслувальному ергометрі $(\mathrm{R}=0,730)$ : вік, зріст, вагу та відсоток жирової маси. У цьому контексті ці вирішальні фізичні та силові показники можуть використовуватися для прогнозування результатів, вирішення завдань відбору спортсменів [33].

Досліджуючи антропометричні та метаболічні детермінанти результативності на дистанції 2000 м на веслувальному ергометрі кваліфікованих спортсменів, що змагаються на міжнародній арені, P. Mikulic на основі отриманих кореляційних та регресійних моделей зробив висновок, що спортсмени, які змагаються на дистанції 6000 м на веслувальному ергометрі, повинні підвищувати м'язову масу тіла та покращувати потужність роботи на рівні вентиляційного порога [36].

У дослідженні S. Ingham et al. вивчались фрізіологічні детермінанти продуктивності під час веслування на дистанції 2000 м на ергометрі у фіналістів змагань 3 веслування на чемпіонаті світу (19 чоловіків та 13 жінок у відкритій ваговій категорії, 4 чоловіки та 5 жінок у легкій ваговій категорії). Учені зазначають, що потужність роботи на рівні $\mathrm{VO}_{2} \mathrm{max}, \mathrm{VO}_{2}$ та потужність роботи при концентрації лактату в крові 4 ммоль · $\pi^{-1}$ і максимальна потужність роботи можуть бути використані для прогнозування результатів на дистанції 2000 м [26].

Предиктори результативних виступів кваліфікованих веслувальників на дистанціях 2000 м та 6000 м розгляда- лися у працях Y. Strykalenko et al. [48, 49], присвячених дослідженню впливу показників максимальної сили на ефективність проходження дистанції в академічному веслуванні. Виявлено суттєву кореляцію між спортивним результатом (веслування на 2000 м) та зареєстрованими показниками тесту «Максимальне прискорення на веслувальному ергометрі «Concept-2», який становив $r=0,754$, що вказує на вплив цього показника на ефективність проходження дистанції. Взаємна кореляційна залежність визначається між показниками відстані 2000 м на ергометрі та результатами тестувань: максимальна тяга лежачи $(r=-0,689)$ і максимальна тяга на «Дибі» $(r=-0,778)$. Кореляційний зв'язок між максимальним прискоренням на веслувальному ергометрі, силові випробування (тяга лежачи $(r=-0,643)$ та тяга на «Дибі» $(r=-0,844)$ були встановлені експериментально [48].

Отримані результати довели, що під час планування тренувальної роботи тренери повинні приділяти увагу розвитку силової витривалості, але також враховувати тісні взаємозв'язки між часом проходження дистанції 2000 м та показниками максимальної сили спортсменів. Тільки завдяки раціональному плануванню тренувальних навантажень спортсмени можуть досягти максимальних результатів у змаганнях найвищого рівня. Експериментально доведено, що показники максимальної сили впливають на ефективність проходження дистанції у веслуванні академічному [48].

Значно доповнюють висвітлен вище питання й наукові праці, які стосуються дослідження взаємозв'язку між показниками максимальної сили та ефективності проходження дистанції у веслуванні академічному на воді та на веслувальному ергометрі «Concept-2» за участю 15 веслувальників високої кваліфрікації - учасників чемпіонатів Європи, світу з веслування академічного та Олімпійських ігор. Виявлено високий кореляційний зв'язок між результатом на веслувальному ергометрі «Concept-2» на дистанції 6000 м та результатом змагань на воді ( $r=0,708)$, а також середній рівень зв'язку між веслуванням на 
веслувальному ергометрі «Concept-2» на дистанції 2000 м та змаганням на воді $(r=0,579)$ [49].

Найвища зворотна кореляційна залежність спостерігалася між показником максимального прискорення на веслувальному ергометрі та силовими випробуваннями (тяга лежачи $r=-0,707$ та тяга «Dyba» $r=-0,881$ ). Автори зазначають, що показники силових якостей позитивно вплинули на швидкісне прискорення веслувальників [49].

Вплив силових якостей на результативність виступів на дистанціі 2000 м на веслувальному ергометрі вивчали Huang Chun-Jung et al. 3ріст та силові характеристики нижніх кінцівок були визначені як провісники результативності на дистанції 2000 м. Результати цього дослідження підтверджують важливість розвитку силових якостей та, зокрема, анаеробних можливостей спортсменів [24].

У дослідженнях F. Akca модель прогнозування, що містить комбінацію анаеробних, силових та антропометричних змінних, виявилася найнадійнішим рівнянням для прогнозування ефективності на веслувальному ергометрі «Concept-2» на дистанції 2000 м $\left(R^{2}=0,92\right.$, SEE $=3,11$ c). Крім того, рівняння, в якому використовувались характеристики анаеробних можливостей, також мало надійний прогноз $\left(R^{2}=0,85\right.$, SEE = 4,27 c). Учені зауважили, що фрізіологічні детермінанти, а саме характеристики анаеробних можливостей спортсменів також повинні бути відображені у моделях, що використовуються для прогнозування результатів та ідентифрікації талантів [12].

T. I. Gee et al. досліджували вплив стратегії подолання дистанції 2000 м на веслувальному ергометрі на її результативність. Встановлено, що стратегія подолання дистанції, що характеризувалася більш рівномірним подоланням першої половини із збільшенням потужності роботи протягом останніх 500 м порівняно зі стратегією подолання дистанції з більшою потужністю роботи на початку дистанції та поступовим зниженням потужності роботи, характеризувалася більш високою концентрацією лакта- ту у крові спортсменів після її подолання [22].

Не оминають своєю увагою науковці й дослідження преддикторів на дистанціях 200, 500 та 1000 м у веслуванні на байдарках і каное (табл. 2). Цілком ймовірно, що цей широкий діапазон тривалості гонки на різних змагальних дистанціях висуває специфічні вимоги до фрунцціонального забезпечення тренувальної та змагальної діяльності спортсменів. Важливу роль відіграють індивідуальні особливості спортсменів та обраної спеціалізації на певній змагальній дистанції $[8,9]$.

Предиктори результативних виступів на змагальних дистанціях 200, 500 та 1000 м комплексно вивчені [52]. Час роботи (середнє значення +/-SD) для 1000,500 і 200 м становив $262,56+/-36,44$ c, $122,10+/-5,74$ c i 41,59 +/- 2,12 с, відповідно. Прогнозована ефективність на всіх дистанціях корелювала 3 рядом фрізіологічних параметрів. Крім того, показники 500 та 200 м корелювали 3 антропометричними характеристиками верхньої частини тіла. Час на дистанції 1000 м прогнозували за вихідною потужністю в точці приросту лактату, вираженою у відсотках максимальної аеробної потужності, та потужністю роботи у 30-секундному тесті на ергометрі, та потужністю роботи у 2-хвилинному тесті на ергометрі (скоригована $R^{2}=0,71$, SEE $=5,72$ c). Час 500 м прогнозували за виконаною роботою та індексом втоми в 30-секундному тесті на ергометрі, потужністю роботи у 2-хвилинному тесті на ергометрі, піковій ізометричній та ізокінетичній функції (скоригована $\mathrm{R}^{2}=0,79$, SEE = 2,49 с). Час 200 м прогнозували за обсягом грудної клітки, шириною плечової кістки, піковою потужністю, виконаною роботою та індексом втоми у 30-секундному ергометричному тесті (скориговане $\mathrm{R}^{2}=0,71$, SEE = 0,71 c) $[37,51,52]$.

у окремих дослідженнях показано, що спортсмени змагаються на рівні вищому їхнього лактатного порога протягом більше 80 с на дистанціях 500 i 1000 м [14-16]. V0 max є загальним показником аеробної підготовленості, і більш високі його рівні до- зволяють спортсменам підтримувати вищі рівні потужності роботи та швидкості човна під час гонки [14-16].

Результати дослідження H. Zouhal et al. показали, що гонки на 500 та 1000 м - це дві різні дистанції за функціональним забезпеченням роботоздатності спортсменів у веслуванні на байдарках, з більшим аеробним внеском на 1000 м. Автори акцентують увагу на необхідності проведення аеробних високоінтенсивних тренувань для елітних спортсменів, які спеціалізуються на дистанції 1000 м, та на анаеробних короткочасних тренуваннях для спорсменів, які спеціалізуються на дистанції 500 м. У дослідженнях взяли участь сім спортсменів 3 міжнародним рейтингом, які спеціалізуються на дистанції 500 м і виступають на дистанції 1000 м (вік: 21,86 \pm 1,68 року, маса тіла: 78,54 $\pm 3,41$ кг, зріст: 1,84 \pm 0,03 м, жировий відсоток: $10,14 \pm 0,69)$. Обґрунтовано використання методу реєстрації акумульованого десріциту кисню (AOD) під час веслування на відкритій воді. AOD на дистанції 500 м був значно вищим, ніж на дистанції 1000 м (18,16 \pm 4,88 проти $9,34 \pm 1,38$ мл $\left.\cdot \mathrm{K}^{-1}, \mathrm{p}<0,05\right)$ [54].

Дискусія. Результати дослідження деяких учених свідчать, що результат елітних веслувальників-одиночників на дистанції 200 м у веслуванні на байдарках і каное становить 35 с, на дистанції 1000 м - 204 с відповідно. Провідні спортсменки-веслувальниці демонструють на дистанції 200 м результат 39-40 с, а виступ у класі човнів К1 на дистанції 500 м триває від 107 до 120 с. Чоловіки і жінки у веслуванні на байдарках і каное змагаються у командних екіпажах К2 та К4 на дистанціях 200, 500 та 1000 м, демонструючи ще вищі результати [14, 51,52].

Веслування академічне - це олімпійський вид спорту, де спортсмени виступають на дистанції 2000 м. Залежно від типу човна, статі та вікової категорії спортсменів, час подолання змагальної дистанції становить 5-8 хв $[34,47]$.

На сьогодні небагато дослідників вивчали енергозабезпечення змагальних дистанцій 200, 500 чи 1000 м. За даними W. C. Byrnes et al., на дис- 
Т а б л и ц я 2. Параметри прогнозування продуктивності веслувальників під час подолання дистанцій 200, 500, 1000, 1500, 2000 та 6000 м у дослідженнях різних авторів

\begin{tabular}{|c|c|c|c|}
\hline $\begin{array}{l}\text { Змагальна } \\
\text { дистанція, м }\end{array}$ & $\begin{array}{l}\text { Вік спортеменів, } \\
\text { років }\end{array}$ & Параметри & Автор \\
\hline \multicolumn{4}{|c|}{ Веслування на байдарках і каное } \\
\hline \multirow[t]{3}{*}{200} & $13-14$ & Антропометричні характеристики & D. López-Plaza et al. [31] \\
\hline & - & $\begin{array}{l}\text { Антропометричні характеристики, потужність та індекс } \\
\text { втоми у 30-секундному тесті }\end{array}$ & K. A. van Someren, G. Howatson [52] \\
\hline & - & Показники максимальної сили & C. W. Pickett et al. [41] \\
\hline \multirow[t]{4}{*}{500} & $13-14$ & Антропометричні характеристики & D. López-Plaza et al. [31] \\
\hline & - & $\begin{array}{l}\text { Потужність роботи та індекс втоми у 30-секундному та } \\
\text { 120-секундному тесті }\end{array}$ & K. A. van Someren, G. Howatson [52] \\
\hline & $20-23$ & AOD & H. Zouhal et al. [54] \\
\hline & 23 & Антропометричні характеристики, $\mathrm{VO}_{2}, \mathrm{AOD}$ & D. Bishop [14] \\
\hline \multirow[t]{3}{*}{1000} & $13-14$ & Антропометричні характеристики & D. López-Plaza et al. [31] \\
\hline & - & $\begin{array}{l}\text { Потужність роботи на рівні анаеробного порога, у 30-се- } \\
\text { кундному та 120-секундному тестах }\end{array}$ & K. A. van Someren, G. Howatson [52] \\
\hline & $20-23$ & AOD & H. Zouhal et al. [54] \\
\hline \multicolumn{4}{|c|}{ Веслування академічне } \\
\hline 1000 & $12-13$ & Антропометричні характеристики, VO 2 max & P. Mikulic et al. [35] \\
\hline \multirow[t]{2}{*}{1500} & $14-15$ & Швидкісно-силові спроможності & C. Giroux et al. [23] \\
\hline & - & $\begin{array}{l}\text { Відсоток м'язової маси, потужність роботи у 30-секундно- } \\
\text { му тесті }\end{array}$ & H. Maciejewski et al. [32] \\
\hline 2000 & $13-17$ & $\begin{array}{l}\text { Антропометричні характеристики, } \mathrm{VO}_{2} \text { max, потужність ро- } \\
\text { боти у 60-секундному тесті }\end{array}$ & D. Cerasola et al. [19] \\
\hline 2000 & $20-28$ & Антропометричні характеристики, силові характеристики & S. Sebastia-Amat et al. [45] \\
\hline 2000 & $19-21$ & Анаеробні, силові та антропометричні характеристики & F. Akca [12] \\
\hline 6000 & $17-26$ & $\begin{array}{l}\text { Відсоток м'язової маси, потужність роботи } \\
\text { на рівні вентиляційного порога }\end{array}$ & P. Mikulic [36] \\
\hline 6000 & $21-34$ & Показники максимальної сили & Y. Strykalenko et al. [49] \\
\hline
\end{tabular}

Примітка. Складено за результатами досліджень автора

танціях 1000 і 500 м внесок аеробного енергозабезпечення становить 82 та 62 \% відповідно. Результати рандомізованих досліджень Н. Zouhal et al. продемонстрували, що внесок аеробного енергозабезпечення був вищим на дистанції 1000 м порівняно 500-метровою дистанцією і становив $86,61 \pm 1,86 \%$ проти 78,30 $\pm 1,85 \%$, відповідно, $p<0,05$. На відміну від цього, на дистанції 200 м у веслуванні на байдарках і каное внесок аеробних джерел становить лише 37 \% [18, 54]. На дистанції 2000 м частка аеробного та анаеробного енергозабезпечення, за даними учених, суттєво відрізня- ється [34]. Ці дослідження демонструють, що більш тривалі змагальні дистанції вимагають більшого аеробного внеску порівняно з короткими. Триває науковий пошук прогностичних критеріїв та предикторів для високого рівня спеціальної роботоздатності спортсменів різного віку з урахуванням спеціалізації на певній змагальній дистанції - 1000, 500 чи 200 м.

Одним із напрямів наукового пошуку у веслуванні на байдарках і каное, представниками якого $\in$ T. R. Ackland et al.; F. Alacid et al. виступають дослідження взаємозв'язку антропометричних, морфологічних характерис- тик веслувальників зі спортивним результатом [11, 13].

За даними Ackland et al. встановлено, що елітні спортсмени-байдарочники мають добре розвинену мускулатуру верхньої частини тіла, високий зріст, вузькі стегна (для чоловіків), низькі показники шкірних складок, збільшену висоту сидіння і біакроміальний діаметр порівняно зі спортсменами нижчої кваліфрікації. Дослідження показали, що спортсмени-байдарочники високого рівня зазвичай мають збільшене стегно, довжину передпліччя та плеча. Окремі дослідники наголошують, що у 
веслуванні на байдарках і каное елітн спортсмени зазвичай вдосконалюють свої вроджені характеристики [11, $15,16]$

На додаток до морфологічних характеристик можуть також бути розглянуті специфічні фрізіологічні можливості спортсменів з урахуванням обраної спеціалізації на певній змагальній дистанції - 200, 500 чи 1000 м у веслуванні на байдарках і каное.

Основні протиріччя стосувалися інтерпретації максимального споживання $\mathrm{O}_{2}$ ( $\left.\mathrm{VO}_{2} \max \right)$ як характеристики одного із провідних компонентів фуннкціонального забезпечення спеціальної роботоздатності веслувальників. У ряді досліджень автори знайшли високий зворотний кореляційний зв'язок між показниками V0,max та часу подолання дистанції 500 та 1000 м у елітних спортсменів [14]. На противагу цим дослідженням, у 2008 р. К. A. van Someren et al. [52] заперечили цей взаємозв'язок для результатів гонок на всіх змагальних дистанціях у веслуванні на байдарках і каное. Це протиріччя розкрите в результаті аналізу даних діагностики фуннкціональних можливостей спортсменів, зареєстрованих у спеціальних умовах тестування з урахуванням спеціалізації 200, 500 і 1000 м у веслуванні на байдарках і каное [1, 2] Результати тестування свідчать, що веслувальники, які показали високі результати на дистанції 200 м у веслуванні на байдарках і 1000 м на каное мали високі, можна сказати унікальні для спринтерів, характеристики аеробної потужності на рівні абсолютного VO ${ }_{2} \max \left(\mathrm{VO}_{2}\right.$ і більше 6,0 л $\left.\cdot \mathrm{XB}^{-1}\right)$ та відносного V0 $\max \left(\mathrm{VO}_{2} / \mathrm{Kг}\right.$ більше 70,0 мл $\left.\cdot \mathrm{XB}^{-1} \cdot \mathrm{Kг}^{-1}\right)$ [1].

Дослідження R. J. Shephard, F. M. Impellizzeri et al. вказують на більш низькі показники абсолютного та відносного $\mathrm{VO}_{2} \max$, що пов'язано 3 переважним залученням до роботи м'язів верхньої частини тіла, порівняно зі спортсменами, які спеціалізуються у веслуванні академічному та велоспорті, через більший відсоток активної м'язовї маси [25, 46].

Висновки. Реалізація методологічного підходу, спрямованого на забезпечення єдності та взаємозв'язку між структурою змагальної діяльності та підготовленості спортсменіввеслувальників, обумовлює субординаційні відносини між складовими змагальної діяльності та підготовленості, слугує основою для впорядкування процесу управління тренувальними та змагальними навантаженнями спортсменів у веслуванні, забезпечує зв'язок структури змагальної діяльності та відповідної їй структури підготовленості з методикою діагностики функціональних можливостей, характеристиками моделей різних рівнів, системою засобів і методів, спрямованих на вдосконалення компонентів підготовленості та змагальної діяльності. Серед найбільш значущих детермінант та предикторів результативних виступів веслувальників на різних змагальних дистанціях вчен розглядають: антропометричні, морфологічні, фрізіологічні характеристики; метаболічні показники та психологічні аспекти.

Відповідно до системи управління тренувальними і змагальними навантаженнями спортсменів у веслуванні узагальнено та систематизовано предиктори результативних виступів веслувальників на різних змагальних дистанціях з урахуванням їхнього віку. Доповнено теоретичні положення стосовно прогностичних критеріїв, предикторів та детермінант ефективного подолання спортсменами різних змагальних дистанцій. Набули подальшого розвитку відомості про параметри прогнозування продуктивності веслувальників під час подолання дистанції 2000 м на веслувальному ергометрі.

Перспективи подальших досліджень полягають в імплементації розроблених теоретичних положень до системи управління тренувальними і змагальними навантаженнями спортсменів у веслуванні.

Конфлікт інтересів. Автор заявляє що відсутній будь-який конфлікт інтересів.

\section{ЛITEPATУРA}

1. Ван Вейлун, Дяченко А. Контроль спеціальної роботоздатності кваліфікованих веслувальників на байдарках і каное на дистанції 500 і 1000 м. Теорія і методика фрізичного виховання і спорту. 2018;(3):10-4.

2. Ван Вейлун, Дяченко А. Специфічні характеристики спеціальної витривалості квалі- фікованих веслувальників на байдарках на дистанції 1000 м. Теорія і методика фрізичного виховання і спорту.2018;(2): 8-13

3. Го П. Совершенствование силовой выносливости квалифицированных спортсменов в гребле на каноэ в подготовительном периоде подготовки [автореферат]. Киев: НУФВСУ; 2010. 25 c.

4. Дьяченко АЮ. Совершенствование специальной выносливости квалифицированных спортсменов в академической гребле. Киев: НПФ «Славутич-Дельфин», 2004. 338 с.

5. Дьяченко В. Динамика показателей функциональной подготовленности спортсменов, специализирующихся в гребле на байдарках и каноэ в годичном цикле подготовки. Наука в олимпийском спорте. 2003;(1):99-105

6. Матвеев ЛП. Основы общей теории спорта и системы подготовки спортсменов. 1999. $312 \mathrm{c}$

7. Платонов ВН. Периодизация спортивной тренировки. Общая теория и ее практическое применение. 2013. 624 с

8. Шинкарук ОА. Отбор спортсменов и ориентация их подготовки в процессе многолетнего совершенствования (на материале олимпийских видов спорта): монография. Киев: Олимпийская лит.; 2011. 360 с.

9. Шинкарук ОА. Подготовка спортсменки высокого класса в гребле на байдарках к главным соревнованиям макроцикла. B: Олімпійський спорт і спорт для всіх: 14-й Міжнар. наук. конгрес, присвячений 80-річчю НУФВСУ; 2010 Жовт 5-8; Київ. Київ: НУФВСУ; 2010. C. 142

10. Шкребтій ЮМ. Управління тренувальними і змагальними навантаженнями спортсменів високого класу в умовах інтенсифікації процесу підготовки [автореферат]. Київ; 2006. 40 с.

11. Ackland TR, Ong KB, Kerr DA, Ridge B. Morphological characteristics of Olympic sprint canoe and kayak paddlers. J Sci Med Sport. 2003 Sep;6(3).285-94. doi: 10.1016/s14402440(03)80022-1.

12. AkÇa F. Prediction of Rowing Ergometer Performance from Functional Anaerobic Power, Strength and Anthropometric Components. Journal of Human Kinetics. 2014; 41. 133-142. 10.2478/hukin-2014-0041.

13. Alacid F, Marfell-Jones M, Muyor JM, López-Miñarro PA, Martínez I. Kinanthropometric comparison between young elite kayakers and canoeists. Coll Antropol. 2015 Mar; 39(1).119-24.

14. Bishop D. Physiological predictors of flat-water kayak performance in women. Eur. J. Appl. Physiol. 2000;82. 91-97. doi: 10.1007/ s004210050656.

15. Borges TO, Bullock N, Coutts AJ. Pacing characteristics of international sprint kayak athletes. Int. J. Perform. Anal. Sport. 2013;13.353364. doi: 10.1080/24748668.2013.11868653.

16. Borges T0, Dascombe B, Bullock N, Coutts AJ. Physiological characteristics of welltrained junior sprint kayak athletes. Int J Sports Physiol Perform. 2015; 10(5), 593-9.

17. Bourgois J, Claessens AL, Vrijens J, Philippaerts R, Van Renterghem, B, Thomis M, Janssens M, Loos R, Lefevre J. Anthropometric characteristics of elite male junior rowers. $\mathrm{Br} \mathrm{J}$ Sports Med, 2000; 34. 213-216

18. Byrnes WC, Kearney JT. Aerobic and anaerobic contributions during simulated canoe/kayak sprint events. Medicine and Science in Sports and Exercise 1997; 29(5). 220.

19. Cerasola D, Bellafiore M, Cataldo A, Zangla D, Bianco A, Proia P, Traina M, Palma A. Predicting the 2000-m Rowing Ergometer Performance 
from Anthropometric, Maximal Oxygen Uptake and 60-s Mean Power Variables in National Leve Young Rowers. Journal of Human Kinetics. 2020 75. 77-83. 10.2478/hukin-2020-0038.

20. Chun-Jung C, Nesser T, Edwards J. Strength and power determinants of rowing performance. J. Exerc. Physiol. Online 2010; 13. 52-57.

21. Cosgrove MJ, Wilson J, Watt D, Grant SF. The relationship between selected physiological variables of rowers and rowing performance as determined by a $2000-m$ ergometer test. J Sports Sci, 1999; 17(11). 845-852.

22. Gee TI, French DN, Gibbon KC, Thompson KG. Consistency of pacing and metabolic responses during 2000-m rowing ergometry. Int $J$ Sports Physiol Perform. 2013 Jan;8(1).70-76. doi: 10.1123/ijspp.8.1.70.

23. Giroux C, Maciejewski H, Ben-Abdessami A, Chorin F, Lardy J, Ratel S, Rahmani A. Correction: Relationship between Force-Velocity Profiles and 1,500-m Ergometer Performance in Young Rowers. International Journal of Sports Medicine. $2017 ; 38$.

24. Huang Chun-Jung, Nesser T, Edwards J. Strength and Power Determinants of Rowing Performance. Journal of Exercise Physiology Online. 2007; 10. 43-50.

25. Impellizzeri FM, Rampinini E, Marcora SM. Physiological assessment of aerobic training in soccer. Journal of Sports Sciences. 2005; 23(6), 583-592.

26. Ingham S, Whyte $G$, Jones $K$, Nevill $A$. Determinants of $2000 \mathrm{~m}$ rowing ergometer performance in elite rowers. Eur. J. Appl. Physiol. 2002; 88, 243-246.

27. Izquierdo-Gabarren M, González R, Sáez E, Izquierdo M. Physiological factors to predict on traditional rowing performance. Eur. J. Appl. Physiol. 2010; 108. 83-92.

28. Jurimae J, Maestu J, Jurimae T, Pihl E. Prediction of rowing performance on single sculls from metabolic and anthropometric variables. J Hum Movement Stud, 2000; 38. 123-136

29. Kellmann M, Klaus-Dietrich G. Changes in stress and recovery in elite rowers during preparation for the Olympic Games. Med Sci Sports Exerc. 2000; 32(3). 676-683.

30. León-Guereño P. Urdampilleta A, Zourdos MC, Mielgo-Ayuso J. Anthropometric profile, body composition and somatotype in elite traditional rowers: A cross-sectional study. Rev. Española Nutr. Diet. 2018; 2. 279-286.

31. López-Plaza D, Alacid F, Muyor JM López-Miñarro PÁ. Sprint kayaking and canoeing performance prediction based on the relationship between maturity status, anthropometry and physical fitness in young elite paddlers. $J$ Sports Sci. 2017. Jun;35(11).1083-1090. doi 10.1080/02640414.2016.1210817.

32. Maciejewski H, Rahmani A, Chorin $F$ Lardy J, Giroux C, Ratel S. The 1,500-m Rowing Performance is Highly Dependent on Modified Wingate Anaerobic Test Performance in NationalLevel Adolescent Rowers. Pediatr Exerc Sci. 2016 Nov;28(4).572-579. doi: 10.1123/pes.2015-0283.

33. Majumdar P, Das A, Mandal M. Physica and strength variables as a predictor of $2000 \mathrm{~m}$ rowing ergometer performance in elite rower.Journal of Physical Education and Sport. 2017. 17(4) 281. 2502-2507.

34. Martin SA, Tomescu V. Energy system efficiency influences the results of 2,000 $\mathrm{m}$ race simulation among elite rowers. Clujul Medical, 2017; 90. 60-65. doi: 10.15386/cjmed-675.

35. Mikulić P, Ruzić L. Predicting the $1000 \mathrm{~m}$ rowing ergometer performance in 12-13-year-old rowers: the basis for selection process? J Sci Med Sport, 2008; 11(2). 218-226.

36. Mikulic P. Anthropometric and metabolic determinants of $6,000-\mathrm{m}$ rowing ergometer performance in internationally competitive rowers. J. Strength Cond. Res. 2009; 23. 1851-1857. doi: 10.1519/JSC.0b013e3181b3dc7e.

37. Mujika I, de Txabarri RG, Maldonado-Martín S, Pyne DB. Warm-up intensity and duration's ecton traditional rowing time-trial performance. Int. J. Sports Physiol. Perform. 2012; 7. 186-188.

38. Nevill AM, Allen SV, Ingham SA. Modelling the determinants of $2000 \mathrm{~m}$ rowing ergometer performance: A proportional, curvilinear allometric approach. Scand. J. Med. Sci. Sport. 2011; 21. 73-78.

39. Penichet-Tomas A, Pueo B, JimenezOlmedo JM. Relationship between experience and training characteristics with performance in nonOlympic rowing modalities. J. Phys. Educ. Sport 2016; 16. 1273-1277.

40. Penichet-Tomás A, Pueo B, Jiménez-OImedo J. Physical performance indicators in traditional rowing championships. J. Sports Med. Phys Fit. 2019; 59. 767-773.

41. Pickett CW, Nosaka K, Zois J, Blazevich AJ. Relationships Between Midthigh Pull Force Development and 200-m Race Performance in Highly Trained Kayakers. J Strength Cond Res. 2019; Jun 19. doi: 10.1519/JSC.0000000000003235.

42. Riechman SE, Zoeller RF, Balasekaran G, Goss FL, Robertson RJ. Prediction of $2000 \mathrm{~m}$ indoor rowing performance using a $30 \mathrm{~s}$ sprin and maximal oxygen uptake. J Sports Sci, 2002 20(9).681-687

43. Russell AP, Le Rossignol PF, Sparrow WA. Prediction of elite schoolboy $2000 \mathrm{~m}$ rowing ergometer performance from metabolic, anthropometric and strength variables. J Sports Sci, 1998 16(8). 749-754.

44. Schabort EJ, Hawley JA, Hopkins WG, Blum $H$. High reliability of performance of well-trained rowers on a rowing ergometer. J Sports Sci. 1999 Aug;17(8). 627-32. doi: 10.1080/026404199365650.

45. Sebastiá Amat $S$, Penichet-Tomás A Jimenez-Olmedo J, Pueo B. Contributions of Anthropometric and Strength Determinants to Estimate $2000 \mathrm{~m}$ Ergometer Performance in Traditional Rowing. Applied Sciences. 2020;10. 6562.

46. Shephard RJ. Science and medicine of canoeing and kayaking. Sports Medicine. 1987; 4(1). 19-33

47. Smith TB, Hopkins WG. Measures of rowing performance. Sports Med, 2012; 42(4). 343 358.

48. Strykalenko Y, Shalar O, Huzar V, Andrieieva R, Zhosan I, Bazylyev S. Influence of the maximum force indicators on the efficiency of passing the distance in academic rowing. Journal of Physical Education and Sport. 2019; 19 (3). Art 218 1507-1512.

49. Strykalenko Y, Shalar O, Huzar V, Voloshynov S, Homenko VI, Serhii B. Efficient passage of competitive distances in academic rowing by taking into account the maximum strength indicators. Journal of Physical Education and Sport 2020; 20 (6), Art 474. 3512-3520

50. van der Zwaard S, Weide G, Levels K, Eikelboom MRI, Noordhof DA, Hofmijster MJ, van der Laarse WJ, de Koning JJ, de Ruiter CJ, Jaspers RT. Muscle morphology of the vastus lateralis is strongly related to ergometer performance, sprint capacity and endurance capacity in Olympic row ers. J. Sports Sci. 2018; 36. 2111-2120.
51. Van Someren KA, Palmer GS. Prediction of 200-m sprint kayaking performance. Can. J. Appl. Physiol. 2003; 28(4). 505-517.

52. van Someren KA, Howatson G. Prediction of flatwater kayaking performance. Int J Sports Physiol Perform. 2008 Jun;3(2).207-218. doi: 10.1123/ijspp.3.2.207.

53. Womack CJ, Davis SE, Wood CM. Effects of training on physiological correlates of rowing ergometry performance. Eur J Appl Strength Cond Res. 1996; 10. 234-238.

54. Zouhal H, Le Douairon Lahaye $S$, Ben Abderrahaman A, Minter G, Herbez R, Castagna C. Energy system contribution to Olympic distances in flat water kayaking (500 and $1000 \mathrm{~m}$ ) in highly trained subjects. J. Strength Cond. Res. 2012;26.825-831. doi: 10.1519/ JSC.0b013e31822766f7.

\section{LITERATURE}

1. Wang Weilung, Diachenko A. Special work capacity control of skilled kayakers and canoeists at 500 and $1000 \mathrm{~m}$ distance. Teoriia i metodyka fizvykhovannia i sportu. 2018;(3):10-4

2. Wang Weilung, Diachenko A. Specific characteristics of special endurance of skilled kayakers at $1000 \mathrm{~m}$ distance. Teoriia i metodyka fiz vykhovannia i sportu.2018;(2): 8-13

3. Go P. Improving strength endurance of skilled canoeists during preparatory training period [author's abstract]. Kiev: NUPESU; 2010. 25 p.

4. Dyachenko AY. Improving special endurance of skilled rowers. Kiev: NPF «SlavutychDelfin», 2004. $338 \mathrm{p}$.

5. Dyachenko V. Dynamics of functional fitness indices in kayakers and canoeists in annual preparation cycle. Nauka v Olimpiyskom sporte. 2003;(1):99-105

6. Matveyev LP. Bases of general sports theory and system of athletes' preparation. 1999. $312 p$

7. Platonov VN. Sports training periodization. General theory and its practical applications. 2013. $624 \mathrm{p}$.

8. Shynkaruk OA. Selection of athletes and their preparation orientation during long-term improvement (on the example of Olympic sports events) monograph. Kiev: Olimpiyskaya literatura.; 2011. $360 \mathrm{p}$

9. Shynkaruk OA. Preparation of elite kayakers for the major macrocycle competitions. In Olympic Sport and Sport for All: 14 Mizhnar. nauk. konhres, prysviachenyi 80-richchiu NUFVU; 2010 Oct 5-8; Kyiv. Kyiv: NUPESU; 2010. P. 142.

10. Shkrebtiy IM. Managing training and competitive loads of top level athletes in conditions of preparation process intensification [author's abstract]. Kyiv; 2006. 40 p.

11. Ackland TR, Ong KB, Kerr DA, Ridge B. Morphological characteristics of Olympic sprint canoe and kayak paddlers. J Sci Med Sport 2003 Sep;6(3).285-94. doi: 10.1016/s1440 2440(03)80022-1.

12. Akça F. Prediction of Rowing Ergometer Performance from Functional Anaerobic Power Strength and Anthropometric Components. Journal of Human Kinetics. 2014; 41. 133-142. 10.2478/hukin-2014-0041.

13. Alacid F, Marfell-Jones M, Muyor JM, López-Miñarro PA, Martínez I. Kinanthropometric comparison between young elite kayakers and canoeists. Coll Antropol. 2015 Mar; 39(1).119-24.

14. Bishop D. Physiological predictors of flat-water kayak performance in women. Eur. 
J. Appl. Physiol. 2000;82. 91-97. doi: 10.1007/

15. Borges TO, Bullock N, Coutts AJ. Pacing characteristics of international sprint kayak athletes. Int. J. Perform. Anal. Sport. 2013;13.353364. doi: 10.1080/24748668.2013.11868653.

16. Borges TO, Dascombe B, Bullock N, Coutts AJ. Physiological characteristics of welltrained junior sprint kayak athletes. Int J Sports Physiol Perform. 2015; 10(5), 593-9.

17. Bourgois J, Claessens AL, Vrijens J Philippaerts R, Van Renterghem, B, Thomis M Janssens M, Loos R, Lefevre J. Anthropometric characteristics of elite male junior rowers. $\mathrm{Br} J$ Sports Med, 2000; 34. 213-216

18. Byrnes WC, Kearney JT. Aerobic and anaerobic contributions during simulated canoe/kayak sprint events. Medicine and Science in Sports and Exercise 1997; 29(5). 220.

19. Cerasola D, Bellafiore M, Cataldo A, Zangla D, Bianco A, Proia P, Traina M, Palma A. Predicting the 2000-m Rowing Ergometer Performance from Anthropometric, Maximal Oxygen Uptake and 60-s Mean Power Variables in National Leve Young Rowers. Journal of Human Kinetics. 2020; 75. 77-83. 10.2478/hukin-2020-0038.

20. Chun-Jung C, Nesser T, Edwards J. Strength and power determinants of rowing performance. J. Exerc. Physiol. Online 2010; 13. 52-57.

21. Cosgrove MJ, Wilson J, Watt D, Grant SF. The relationship between selected physiological variables of rowers and rowing performance as determined by a $2000-m$ ergometer test. J Sports Sci, 1999; 17(11). 845-852.

22. Gee TI, French DN, Gibbon KC, Thompson KG. Consistency of pacing and metabolic responses during 2000-m rowing ergometry. Int J Sports Physiol Perform. 2013 Jan;8(1).70-76. doi: 10.1123/ijspp.8.1.70.

23. Giroux C, Maciejewski H, Ben-Abdessamie A, Chorin F, Lardy J, Ratel S, Rahmani A. Correction: Relationship between Force-Velocity Profiles and 1,500-m Ergometer Performance in Young Rowers. International Journal of Sports Medicine. $2017 ; 38$.

24. Huang Chun-Jung, Nesser T, Edwards J. Strength and Power Determinants of Rowing Performance. Journal of Exercise Physiology Online. 2007; 10. 43-50.

25. Impellizzeri FM, Rampinini E, Marcora SM. Physiological assessment of aerobic training in soccer. Journal of Sports Sciences. 2005; 23(6), 583-592.

26. Ingham S, Whyte G, Jones K, Nevill A Determinants of $2000 \mathrm{~m}$ rowing ergometer performance in elite rowers. Eur. J. Appl. Physiol. 2002; $88,243-246$

27. Izquierdo-Gabarren M, González R, Sáez E, Izquierdo M. Physiological factors to predict s004210050656.

on traditional rowing performance. Eur. J. Appl. Physiol. 2010; 108. 83-92.

28. Jurimae J, Maestu J, Jurimae T, Pihl E. Prediction of rowing performance on single sculls from metabolic and anthropometric variables. Hum Movement Stud, 2000; 38. 123-136

29. Kellmann M, Klaus-Dietrich $\mathrm{G}$. Changes in stress and recovery in elite rowers during preparation for the Olympic Games. Med Sci Sports Exerc 2000; 32(3). 676-683.

30. León-Guereño $P$, Urdampilleta A, Zourdo MC, Mielgo-Ayuso J. Anthropometric profile, body composition and somatotype in elite traditiona rowers: A cross-sectional study. Rev. Española Nutr. Diet. 2018; 2. 279-286.

31. López-Plaza D, Alacid F, Muyor JM, López-Miñarro PÁ. Sprint kayaking and canoeing performance prediction based on the relationship between maturity status, anthropometry and physical fitness in young elite paddlers. Sports Sci. 2017. Jun;35(11).1083-1090. doi: 10.1080/02640414.2016.1210817.

32. Maciejewski $H$, Rahmani $A$, Chorin $F$ Lardy J, Giroux C, Ratel S. The 1,500-m Rowing Performance is Highly Dependent on Modified Wingate Anaerobic Test Performance in NationalLevel Adolescent Rowers. Pediatr Exerc Sci. 2016 Nov;28(4).572-579. doi: 10.1123/pes.2015-0283.

33. Majumdar $P$, Das A, Mandal M. Physical and strength variables as a predictor of $2000 \mathrm{~m}$ rowing ergometer performance in elite rower.Journal of Physical Education and Sport. 2017. 17(4) 281. 2502-2507.

34. Martin SA, Tomescu V. Energy system efficiency influences the results of 2,000 $\mathrm{m}$ rac simulation among elite rowers. Clujul Medical, 2017; 90. 60-65. doi: 10.15386/cjmed-675.

35. Mikulić P, Ruzić L. Predicting the $1000 \mathrm{~m}$ rowing ergometer performance in 12-13-year-old rowers: the basis for selection process? J Sci Med Sport, 2008; 11(2). 218-226.

36. Mikulic P. Anthropometric and metabolic determinants of $6,000-\mathrm{m}$ rowing ergometer performance in internationally competitive rowers J. Strength Cond. Res. 2009; 23. 1851-1857. doi 10.1519/JSC.0b013e3181b3dc7e.

37. Mujika I, de Txabarri RG, Maldonado-Martín S, Pyne DB. Warm-up intensity and duration's ecton traditional rowing time-trial performance. Int. J. Sports Physiol. Perform. 2012; 7. 186-188.

38. Nevill AM, Allen SV, Ingham SA. Modelling the determinants of $2000 \mathrm{~m}$ rowing ergomete performance: A proportional, curvilinear allometric approach. Scand. J. Med. Sci. Sport. 2011; 21. 73-78.

39. Penichet-Tomas A, Pueo B, Jimenez Olmedo JM. Relationship between experience and training characteristics with performance in nonOlympic rowing modalities. J. Phys. Educ. Sport. 2016; 16. 1273-1277.

\section{ІНФОРМАЦІЯ ПРО АВТОРА}

Русанова Ольга Михайлівна https:orcid.org/ 0000-0001-7495-7030, rusanova2080@gmail.com Національний університет фізичного виховання і спорту України, 03150, Київ, вул. Фізкультури, 1

\section{INFORMATION ABOUT THE AUTHOR}

Rusanova Olga https:orcid.org/0000-0001-7495-7030, rusanova2080@gmail.com National University of Ukraine on Physical Education and Sport, 03150, Kyiv, Fizkul'tury str., 1.
40. Penichet-Tomás A, Pueo B, Jiménez-0Imedo J. Physical performance indicators in traditional rowing championships. J. Sports Med. Phys. Fit. 2019; 59. 767-773

41. Pickett CW, Nosaka K, Zois J, Blazevich AJ. Relationships Between Midthigh Pull Force Development and 200-m Race Performance in Highly Trained Kayakers. J Strength Cond Res. 2019; Jun 19. doi: 10.1519/JSC.0000000000003235.

42. Riechman SE, Zoeller RF, Balasekaran G, Goss FL, Robertson RJ. Prediction of $2000 \mathrm{~m}$ indoor rowing performance using a $30 \mathrm{~s}$ sprint and maximal oxygen uptake. J Sports Sci, 2002; 20(9).681-687

43. Russell AP, Le Rossignol PF, Sparrow WA. Prediction of elite schoolboy $2000 \mathrm{~m}$ rowing ergometer performance from metabolic, anthropometric and strength variables. J Sports Sci, 1998; 16(8). 749-754.

44. Schabort EJ, Hawley JA, Hopkins WG, Blum $\mathrm{H}$. High reliability of performance of well-trained rowers on a rowing ergometer. J Sports Sci. 1999 Aug;17(8). 627-32. doi: 10.1080/026404199365650

45. Sebastiá Amat S, Penichet-Tomás A, Jimenez-Olmedo J, Pueo B. Contributions of Anthropometric and Strength Determinants to Estimate $2000 \mathrm{~m}$ Ergometer Performance in Traditional Rowing. Applied Sciences. 2020;10. 6562.

46. Shephard RJ. Science and medicine of canoeing and kayaking. Sports Medicine. 1987; 4(1). 19-33.

47. Smith TB, Hopkins WG. Measures of rowing performance. Sports Med, 2012; 42(4). 343358

48. Strykalenko Y, Shalar O, Huzar V, Andrieieva R, Zhosan I, Bazylyev S. Influence of the maximum force indicators on the efficiency of passing the distance in academic rowing. Journal of Physical Education and Sport. 2019; 19 (3). Art 218. 1507-1512.

49. Strykalenko Y, Shalar O, Huzar V, Voloshynov S, Homenko VI, Serhii B. Efficient passage of competitive distances in academic rowing by taking into account the maximum strength indicators. Journal of Physical Education and Sport 2020; 20 (6), Art 474. 3512-3520.

50. van der Zwaard S, Weide G, Levels K, Eikelboom MRI, Noordhof DA, Hofmijster MJ, van der Laarse WJ, de Koning JJ, de Ruiter CJ, Jaspers RT. Muscle morphology of the vastus lateralis is strongly related to ergometer performance, sprint capacity and endurance capacity in Olympic rowers. J. Sports Sci. 2018; 36. 2111-2120.

51. Van Someren KA, Palmer GS. Prediction of 200-m sprint kayaking performance. Can. J. Appl. Physiol. 2003; 28(4). 505-517.

52. van Someren KA, Howatson G. Prediction of flatwater kayaking performance. Int J Sports Physiol Perform. 2008 Jun;3(2).207-218. doi: 10.1123/ijspp.3.2.207.

53. Womack CJ, Davis SE, Wood CM. Effects of training on physiological correlates of rowing ergometry performance. Eur J Appl Strength Cond Res. 1996; 10. 234-238.

54. Zouhal H, Le Douairon Lahaye S, Ben Abderrahaman A, Minter G, Herbez R, Castagna C. Energy system contribution to Olympic distances in flat water kayaking (500 and $1000 \mathrm{~m}$ ) in highly trained subjects. J. Strength Cond. Res. 2012;26.825-831. doi: 10.1519/ JSC.0b013e31822766f7.

Надійшла 21.12.2020 